\title{
Idrættens veje og steder
}

\section{AfJørn Hansen og Niels Kayser Nielsen}

Som bekendt var 1994 det år, hvor Dansk Idrætshistorisk Forening Krop og Kultur kunne fejre 10 års jubilæum. I den anledning havde Idrættens Forskningsråd bevilliget penge til, at bibliotekar Ole Christensen Odense Universitetsbibliotek kunne udarbejde en oversigt over den humanistiske og samfundsfaglige idrætslitteratur. Arbejdet har ført til publikationene Idrcetsbibliografi. 10 års dansk humanistisk og samfundsfaglig idrcetslitteratur 1984-1994. I bibliografien er registreret danske forfattere eller artikler omfattende danske forhold. Registreringen omfatter monografier samt artikler i bøger og tidsskrifter. I alt er det blevet til mere end 1200 opslag, så man kan vel tillade sig at sige at arbejdet har båret frugt.

De mange opslag i Idratsbibliografien viser såvel idrættens som idrætsforskningens mangfoldige veje at gå. Årets debat inden for den humanistiske og samfundsfaglige forskning har handlet om Claus Bøje og Henning Eichbergs Idrcettens tredje vej. Om idratten i kulturpolitikken. Bogen er bind to i den kulturpolitiske skriftserie om kulturens politik, som kulturminister Jytte Hilden har iværksat. Den tredje vej er et forsøg på et opgør med såvel en dualistisk måde at se idrætten på - elite $e l$ ler bredde i stedet for $o g$ mangfoldighed som et fors $\emptyset \mathrm{g}$ på at installere en trialektisk tænkemåde, hvor forhold beskrives således at den kririske opmærksomhed for kompleksiteten i de eksisterende spændinger og modsætninger skærpes.
Mange af synspunkterne i bogen er tidligere blevet luftet af såvel Claus Bøje som Henning Eichberg. Interessant har det derfor været at følge den til tider heftige debat bogen kom til at afføde i og med den blev en publikation i kulturministeriel regie. Vi vil ikke her gå nærmere ind $\mathrm{i}$ en diskussion af indholdet, som appendix til denne litteraturorientering bringes en citatmosaik over anmeldelser vedrørende Idraetten tredje vej samlet af Henning Eichberg.

Hvad selve idrætsaktiviteterne angår finder disse stadig nye veje. I antologien $\mathrm{Hoo}$ ked - om vanvid og cestetik $i$ sport og kropskultur redigeret af Verner Møller, Jørgen Povlsen og Kurt Lüders kan man læse om ekstase, laksefiskeri, skihopperen Eddie the Eagle og kroppen i spillemaksiner. Dertil kommer overordnede diskussioner om sundhedsidræt i relation til »livsbekræftende« vanvidsaktiviteter som bungyjump og bjergklatring.

Man kan vælge at se vanvidsidrætten som et nybrud inden for idræts- og kropkulturen, som en bevægen sig væk fra 1980'ernes regelrette sports- og fittnesskrop. Er dette tilfældet supplerer Niels Kayser Nielsens artikelsamling Stil og ballade. Modstridende tendenser og paradokser i 1980'ernes kropskultur og Hooked hinanden. Begge publikationer rummer en kritik af forsøg på at arbejde med et snævert og operationaliserbart sundhedsbegreb og sætter i stedet en mere åben levemåde og livsstil uden at opfatte dette som væren- 
de usundt. Niels Kayser skriver underholdende om blandt andet »Lättapigen som død sild«,«Pommes frites på Rigshospita-let« og »Kost mellem begær og kontrol«. Sigtet er også her som i Hooked hovedsagelig rettet mod mellemlagenes ændrede levemåde.

Det er ikke tilfældigt at idrætsforskningen »har haft ondt i sundheden «. Siden tabet af gymnastikkens sundhedsreference i såvel samfund som skole har man vanskeligt kunne udfylde begrebet sundhedsidræt. Flere idrætsforskere har rettet et kritisk blik mod selve sundhedsbegrebet, og disse bliver nu støttet af antologien Sundhedsbegreber - filosofi og praksis redigeret af Uffe Juul Jensen og Peter Fuur Andersen. Bidragene $i$ antologien er et resultat af forskningsprojektet »Sundhed, menneske og kultur «, hvor forskere med forskellige humanistiske tilgange - filosofi, etnologi og psykologi - yder et bidrag til udviklingen af en sundhedsforskning, der kan supplere den medicinsk dominerede forskning vedrørende sundhed og sundhedsfremme. Centralt står opfattelsen af, at afklaringen af sundhedsbegrebet er en del af en mere omfattende filosofisk problematik.

En diskussion af begreber er også på tale, når Arne Rahbek i Hellere brcekke en arm end tabe en kamp $\mathrm{i} \gg$ Arbejderhistorie « nr. 41, 1993 kritiserer Jørn Hansens problematisering af, at der skulle findes en speciel slags arbejderfodbold. En diskussion, der i »Arbejderhistorie« nr. 43, 1994 følges op af Laila Ottesen i artiklen Kampene i og om sporten, hvoror hun mener, at de to forfattere reelt er enige om, at der i starten af idrætsbevægelsen fandtes en særlig arbejderidræt. Men at forskellen ikke fremkommer i de enkelte idrætsdiscipliner, hvis regler nu engang er entydigt fastlagte; istedet fremkommer forskellene via opfattelserne af idrætsdisciplinerne og de idrætsmiljøer, der opbygges omkring disse.

I Tyskland søgte arbejderbevægelsen en altenativ idræt. Dette beskrives i Jörg Wetterichs afhandling Bewegungskultur und Körpererziehung in der sozialistischen Jugendarbeit 1893 bis 1933. I dette grundige arbejde behandles fors $\emptyset$ get på under indflydelse af socialistisk ideologi og mønsteret fra livsreformbevægelsen at danne et modkoncept til den konventionelle sport. Et koncept, der har mange ligheder med nutidens tyske bredde- og fritidssport.

Generelt er der igen gang i tysk idrætsforskning. Herhjemme kan man især hæfte sig ved den blomstrende tyske forskning $\mathrm{i}$ fodboldkultur og -historie. Ikke på noget tidligere tidspunkt har man set sà mange publikationer som inden for de sidste par år. Sven Güldenpfennig har lavet en stor samleanmeldelse af dem i tidsskriftet Sozial- und Zeitgeschichte des Sports 1994: 2. Han hæfter sig her ved visse fællesmønstre i denne fodboldlitteratur, nemlig en centrering omkring et niveau, som han kalder »fodbold er mere end.... «, dvs. fodboldens sociale og kulturelle betydning; en afs $\varnothing \mathrm{g}$ ning af bestemte imagedannelser i fodboldkulturen, såsom i tilknytning til bestemte hold og bestemte spillere; en historisk interesse i spillets begyndelsesfase; en søgen efter nationale, regionale og lokale særegenheder $\mathrm{i}$ spillet såsom en typisk »engelsk « spillestil, en typsisk »Ruhr-profil«, en typisk »proletarisk « stil etc.; intellektuelles hyldest til fodboldspillet og dets mytologiske univers; en kritik af spillets antiemancipatoriske sider og den kommercielle udhuling af fodboldkulturen.

Af de vægtigste bøger kan nævnes Dietrich Schulze-Marmeling: Der gezähmte Fussball. Zur Geschichte eines subversiven Sports, der beskæftiger sig med mulighe- 
derne for at redde fodboldkulturens oprørske og frisættende sider midt i kommercialiseringen. Helmut Böttingers Kein Mann, kein Schuss, kein Tor. Das Drama des deutschen Fussballs er en slags fodboldens mentalitetshistorie, der er optaget af spillets artistiske og æstetiske aspekter. Werner Langmaacks FC St. Pauli. Glaube, Liebe, Hoffnung. Geschichten rund um den sympathischtesten Verein der Welt er en hyldest til forfatterens yndlingsklub, der i sin sans for lokalmiljøets særlige kulturelle profil er beslægtet med Nick Hornby's berømte kærlighedserklæring til Arsenal i bogen Fever Pitch. Alt i alt er der megen inspiration for dansk idrætsforskning at hente i denne nye tyske trend. Her har man lavet noget af det, som mange af os går og drømmer om vedr. danske forhold, hvor vi fortsat i udpræget grad savner belysning af fodboldens historie og dens sociokulturelle betydning.

Hvad en sådan belysning kan indebære, har man et eksempel på i Per Nilssons disputats Fotbollen och moralen. En studie av fyra allsvenska fotbollsföreningar, omhandlende klubberne Brage, IFK Göteborg, GAIS og Malmö FF. Med udgangspunkt i Bourdieus begreber om socialt felt, habitus og kulturel kapital indkredses de fire klubbers særlige profiler, ikke mindst $i$ henseende til efterlevelse af fair play. Trods dette ærinde er bogen herligt befriet for moraliseren og tværtimod fyldt af megen, empirisk underbygget, bestemmelse af klubkultur og »stil«. Forskellen på de to store klubber i Sverige; IFK Göteborg og Malmö FF, opridses tydeligt, ligesom relationen i Nordens fodboldhovedstad - Göteborg - mellem GAIS og IFK er skildret med megen sans for forskelle og ligheder mellem disse to store arbejderklubber.

Ønsker man at gå videre med disse distinktioner har man en guldgrube i GAIS's
100 års jubilæumsbog Makrillar, kval och gröna raketer. For alle elskere af denne klub med dens helt unikke inkarnation af göteborgskhed er bogen uomgængelig. Dels er den detaljeret med hensyn til klubbens ældste historie, dels er den givtig, hvad angår beskrivelse og analyse af klubbens tilhængere med udskrifter af nogle af den stærke fanklubs slagsange, ligesom man her får historien om, hvorfor de göteborgske klubber skiftede spillested fra Nya Ullevi til det traditionsrige Gamla Ullevi. Typisk for bogens humor og humør er det hyldestdigt til klubben, som svensk sportjournalistiks filur, Lars-Gunnar Björklund, anfører:

\section{Lelle Osborn sa til fröken \\ livet vore la en öken \\ utan glass och rostad majs \\ spunnet socker - åsså GAIS}

\section{Heja GAIS!}

En anden af de svenske traditionsforeninger, Hammarby fra »Söders höjder « i Stockholm, er emnet for bysociologen Mats Franzéns artikel »Hammarby och Söder «, in NordNytt nr. 53. Artiklen er en ventilation af de foreløbige resultater af Franzéns projekt om denne gamle arbejderklubs begivenhedsrige historie i mellemkrigstiden, hvor det overbevisende påvises, hvor vigtige de lokale rødder (i begge betydninger af ordet) var for denne klub, som senere skulle blive for den klub, som introducerede alsangen på de svenske stadions.

Det var som bekendt i Sverige, at Danmark i 1992 vandt Europamesterskabet i fodbold. Under fodbold-EM fulgte en række samfundsforskere de forskellige landes tilhængere på tæt hold. Dette har ført til publikationen Mellan Karneval och Huliganism - en antologi om den moderna supporterkulturen redigeret af Tore Brännberg 
(1993). I flere af artiklerne inddrages den righoldige engelske og tyske litteratur om tilskuerproblemer, mest interessant er dog - karakteristikken af de forskellige deltagerlandes supportere.

Men svensk idrætshistorie er andet end fodbold. Det kan man forvisse sig om i Jan Lindroths seneste bog: Gymnastik mellan lek och idrott, För och emot fria kroppsövningar $i$ det svenska läroverket 1878-1928, som med sædvanlig kildekritisk grundighed gør rede for, hvorledes Ling-gymnastikken forsvarede sine bastioner $\mathrm{i}$ den svenske gymnasieskole. Man kan også kikke i Svenska idrottshistoriska föreningens årsskrift 1993, hvor især to artikler påkalder sig opmærksomhed, nemlig Christer Bjurwills »Kroppens fenomenologi«, som er et godt bidrag til den standende debat mellem krop som repræsenation og krop som substans. Artiklen kan også læses som et udtryk for den forskning i kroppens tavse viden, der er i gæring. Helt forskellig fra denne filosofiske tilgang er Christer Ericssons historisk-sociologiske artikel »Idrotten i brukssamhället - synpunkter och exempel«, som er en komparativ studie i idrættens historie $\mathrm{i}$ to mindre svenske byer, nemlig henholdsvis bandybyen Lesjöfors og Torshälla. Udover det komparative blik, som i sig selv er fortjentsfuldt, er artiklen interessant ved at påvise idrættens betydning som socialt og kulturelt »kit«. Også her viser det sig, at idrætten er »mere end...«.

Apropos idrætshistoriske årsskrifter er det glædeligt at se den nye finske idrætshistoriske forenings første årsskrift. Ganske vist er de fleste af artiklerne skrevet på finsk, hvilket selvsagt forskærtser læsemulighederne i de $\varnothing v$ rige nordiske lande, men der er dog også artikler på svensk. I betragtning af den finske idrætshistoriske og - sociologiske forsknings høje stade er der grund til at se frem til spændende bidrag herfra i de kommende år.

Dette høje niveau kan man se eksempler på i det temanummer af International Review for the Sociology of Sport om »Narrative Sociology«, som Henning Eichberg har redigeret. Her er der bidrag af bl. a. Esa Sironen om erindringens betydning for kropskulturel forskning, af Martti Silvennoinen om hans barndoms skihophelte $\mathrm{i}$ Kuopio, af Soile Veijola om kønsforskelle i idrætten i en belæst og sprogligt uhyre velskrevet artikel. Fra Danmark bidrager Henning Eichberg selv med en oversigtsartikel, der indkredser den særlige skandinaviske kropskultur-sociologi, ligesom Søren Nagbø1 - som altid veloplagt --skriver om badeanstalten Helgoland på Amager, og Laila Ottesen i sin artikel om Jane og Anne demonstrerer, hvor langt man kan komme med et biografisk-livshistorisk perspektiv.

Men ellers er den store begivenhed i den finske idrætshistoriske forskning Henrik Meinanders disputats Towards a Bourgeois Manhood. Med udgangspunkt i en gymnasieskole $\mathrm{i}$ hver af de nordiske hovedstæder analyseres idrættens betydning for den mandlige opdragelse inden for borgerskabet. Meinander, som er elev af J.A. Mangan, er her som altid kildekritisk grundig med anvendelse af såvel trykt som utrykt materiale, hvor man ser eksempel på omhyggelige arkivstudier, uden at denne traditionelle tilgang af den grund går ud over den samfundsmæssige perspektivering. Bogen er den første store komparative internordiske studie $\mathrm{i}$ idrætshistorie og er alene herved uhyre velkommen, men bogen viser samtidig hvor langt idrætshistorien kan nå, når den bevæger sig ud over det snævert institutionshistoriske perspektiv og heller ikke ser de kildekritiske studier som værdifulde i sig selv. Meinanders 
funktionelle kildeanvendelse er så afgjort en gevinst.

I rækken af internationale studier af sportshistorien, hvor ovennævnte J.A. Mangan står som redaktør udkom i 1993 Derek Birleys Sport and the making of Britain, hvor sammenhængen mellem sporten og det at være engelsk sættes ind i historiens lange linie for at kulminere med missionærens brug af legemskulturen under imperialismen.

Som yderligere et eksempel på idrætsforskning over grænserne kan nævnes Körpersprache. Über Identität und Konflikt redigeret af Knut Dietrich og Henning Eichberg. Ud fra et fors $\emptyset \mathrm{g}$ på at arbejde med en kropsantropologisk forståelse behandles tre overordnede temaer: Sammenhængen mellem kulturel konflikt og kropssprog - ved blandt andet Jørn Møller, Knut Dietrich og Jean-Jacques Barreau; mellem kroppens habitus og bevægelseskulturen hos ældre, arbejdere og medicinere - ved blandt andet Jørgen Povlsen, Jørn Hansen, Søren Nagbøl, Kirsten Roessler og Reinhard Stelter samt arbejdet med at etablere en antropologiteori på basis af kroppen ved David le Breton, Knut Dietrich og Henning Eichberg. Dansk idrætsforskning er rigt repræsenteret ud over grænserne.

Dette fremgår også af Søren Nagbøl og John Bales bog A View of English Football: Sport and Sense of Place, der er publiceret i Jyväskylä i Finland, udgivet af Jyväskylä Universitets institut for Socialpolitisk forskning. Bogen rummer en række af Søren Nagbøls fremragende billeder fra en rundrejse til engelske stadion, ledsaget af hans egne fænomenologiske sanseiagttagelser og John Bales perspektiveringer heraf.

Samme John Bale har i 1994 fulgt sin bog Sport, Space and the City fra i fjor om forvandlingen af britisk fodbold på og om- kring stadion'erne op med yderligere en bog: Landscapes of Modern Sport. Denne bog, dedikeret til John Bales »Nordic Friends « sammenfatter den walisiske geograf og idrætssociologs mangeårige forskning $\mathrm{i}$ idrættens geografi. Bogen er den første store fremstilling af idrettens topografi og er alene herved et væsentligt bidrag til idrætsforskningen. Men den er meget mere: der er udover en Foucault-inspireret analyse af det moderne idrætslandskabs indbyggede disciplinering også en gennemgang af idrætsfaciliteternes historie tilbage til antiken. John Bales belæsthed og udogmatiske holdning $\mathrm{g} ø \mathrm{r}$ det ligeledes muligt at indkredse den moderne sports dobbelthed af undertrykkelse og civilisering. Det sker ikke mindst i et righoldigt kapitel med titlen »Stadiums as Gardens, Athletes as Pets«, som er et nyttigt korrektiv til alt for firkantede og »frelste « kritikker af sportens væsen. Her er der inspiration at hente for den forskning i idrættens nuancerigdom og kulturelle pluralisme, som man i dag kan ane konturerne af, oven på de mere fastlåste opfattelser fra 1970'erne og 1980'erne.

Den flittige John Bale har ligeledes, sammen med Joe Maguire, redigeret antologien The Global Arena. Athletic Talent Migration in an Interdependant World, der analyserer sportsfolks vandringer over grænserne som enhver anden type af arbejdskraft med fri bevægelighed. Dette projekt sættes i relief af, at der aldrig har været så mange udenlandske professionelle i den engelske fodboldliga som i sæsonen 1994-95. At der er også er tale om udenlandske spillere andre steder, kan man se i Kalevi Olin og Matti Penttiläs artikel om udenlandske spillere i Finland i ikke kun fodbold, men også ishockey og basketball. Der er tale om et stort kontingent østeuropæiske spillere, men også brasilianere (i 
fodbold). Bogen giver i $\varnothing v$ vrigt lejlighed til at stifte bekendtskab med et par af de i øjeblikket mest interessante idrætshistorikere i -Europa, nemlig Pierre Lanfrance, som arbejder i Firenze, og franskmanden Christian Bromberger, som bidrager med en ganske fremragende artikel om publikums reaktioner på udenlandske spillere $\mathrm{i}$ henholdsvis Napoli og Marseille, hvor Helge Bronée fra ØB i sin tid spillede - han kaldes »extravagant « $\mathrm{i}$ artiklen og staves $\mathrm{i}$ $\emptyset$ vrigt $»$ Bromée«. Men ellers er der ikke mange fingre at sætte på Brombergers bidrag.

I den engelsksprogede verden har to centrale publikationer om kvinder i sporten set dagens lys. I England har Jennifer Hargreaves bidraget med Sporting females. Critical issues in the history and sociology of women's sport, hvor der gives analyse af kvindeidrætten i England fra det 19. århundrede til idag. I USA har Greta L. Cohen redigeret antologien Women in sport. Issues and Controversies . Kvindidrætten vurderes her ud fra en både historisk, økonomisk, sociologisk, fysiologisk og psykologisk tilgang.

Den lokalhistoriske idrætsforskning har aldrig været særlig fremtrædende herhjemme. Det er derfor interessant at se de eksempler herpå, som nu så småt dukker op. De lokalhistoriske årbøger er her nok værd at frekventere. Således rummede $\mathrm{Fra} \mathrm{Fre-}$ deriksborg Amt 1992 en interessant artikel af Lars Bjørn Madsen om cykling i Nordsjælland omkr. århundredskiftet 1900; F. Th. Michaelsen har i Stavn (1992), som udgives i Faaborg, skrevet om oprettelsen af Haagerup Friluftsbad, ligesom Edvard Køhrsen i Koldingbogen fra 1992 har skrevet om Harte Gymnastik- og Idrætsforening.
R $\phi d d e r$ - fynboers historie $i$ arbejde og fritid udgivet af Historisk Udvalg, der er sammensat af repræsentanter fra arbejderbevægelsens organisationer, fra museer og lokalarkiver på Fyn udgav i forbindelse med landsstævnet i Svendborg et lille temanummer om »Folkesporten på Fyn«. Heftet indeholder blandt andet to små originale bidrag om arbejderidrætten og cykelsporten på Fyn,

Denne type forskning er i 1994 fulgt op af et spændende speciale ved Historisk Institut, OU, af Erik Pold om idrætslivet i henholdsvis Skårup og Nr. Åby på Fyn, hvor forfatteren beskæftiger sig med relationen mellem gymnastik og sport: arbejdede man sammen herom, eller var der tale om et vandskel? Denne problemsitilling står også i centrum i Niels Kayser Nielsens artikler »Fra gymnastik til sport. Om idrætten på landet i mellemkrigstiden « i Journalen. Lokal- og kulturhistorisk tidsskrift 1994, nr. 4. og »To idrætsforeninger på landet i mellemkrigstiden - Trelde og Herslev « i Vejle Amts Årbog 1994. I begge tilfælde gøres der op med myten om, at gymnastik og sport traditionelt har været modpoler. Når forholdet mellem dem anskues ud fra dagligdagen $i$ en lokal idrætsforening i mellemkrigstiden, bliver det tydeligt, at de snarere supplerede hinanden, og at sporten var velegnet til overvindelse af den foreningskrise, der gjorde sig gældende mange steder i de første år af 1930'erne. I artiklen »Højskole og sport - om idrætten i Vejen« i Magasin fra Det kongelige Bibliotek, vol. 9 , nr. 2 påvises det, at der fra starten var tætte forbindelser af såvel økonomisk som social og personlig karakter mellem $h ø j-$ skolemiljøet i Askov og sporten i Vejen. Endelig står det lokalhistoriske perspektiv også i focus i hans artikel »Dem fra Farre med det røde V. Den belyste krop og kroppens udstråling «, in: Anders Linde-Laursen 
og Jan Olof Nilsson (red.): Möjligheternas landskap. Nordiske kulturanalyser. København og Stockholm 1994. Denne bog rummer desuden en artikel af Kenneth Olwig, »Landskab, landscape og kroppen« om kroppens placering inden for henholdsvis en nordisk og en engelsk/italiensk-inspireret landskabsopfattelse - og så er man igen tilbage ved forskningssamarbejde hen over grænserne. 
